Original Research Article

\title{
A randomised study of evaluation of antiulcerogenic activity of quercetin in rats
}

\author{
Altaf Hussain Shaik ${ }^{1}$, Venkata Siva Prasadu M. ${ }^{2 *}$
}

${ }^{1}$ Department of Pharmacology, Nimra Institute of Medical Sciences, Jupudi, Vijayawada, Andhra Pradesh, India ${ }^{2}$ Department of Pharmacology, Kurnool Medical College, Kurnool, Andhra Pradesh, India

Received: 19 September 2018 Accepted: 22 October 2018

\section{*Correspondence to:}

Dr. Venkata Siva Prasadu M, Email: dr.mvsp1986@ gmail.com

Copyright: (C) the author(s), publisher and licensee Medip Academy. This is an openaccess article distributed under the terms of the Creative Commons Attribution NonCommercial License, which permits unrestricted noncommercial use, distribution, and reproduction in any medium, provided the original work is properly cited.

\begin{abstract}
Background: Peptic ulcer is very common disease. Peptic ulcer results probably due to an imbalance between aggressive factors (acid, pepsin, H. pylori) and defensive factors (gastric mucus, prostaglandins and bicarbonate secretion). Whatever may be the cause of peptic ulcer, it is the gastric acid that prevents ulcer healing and maintain the ulcer. Therefore, most of the drugs available for treatment of peptic ulcer either neutralize the secreted acid or decrease the acid secretion.

Methods: The study was conducted on albino rats (Wistar) of 200-250g and maintained under standard conditions (room temperature $24-27^{\circ} \mathrm{C}$ and humidity $60-65 \%$ ) with $12 \mathrm{~h}$ light and dark cycle. The food in the form of dry pellets (Amrut Lab., hyd) and water were available ad libitum. The animal experiments were approved by the ethics committee of the institute.

Results: In pyloric ligation model, the rats pre-treated with quercetin showed highly significant protection $(\mathrm{p}<0.001)$ when compared to control group and significant protection when compared to ranitidine pre-treated group ( $\mathrm{p}<0.05)$. In indomethacin model, both quercetin and ranitidine pre-treated groups showed significant protection when compared to control group $(\mathrm{p}<0.01)$.

Conclusions: In conclusion, it appears that quercetin possess anti-ulcerogenic principles like flavanoids, phenolic compound and caratinoid. These phytoconstituents provides protection against gastric mucosal damage induced by pylorus ligation, aspirin and ethanol, through inhibition of gastric acid, pepsin, histamine and free radical and stimulation of mucus secretion.
\end{abstract}

Keywords: Gastric ulcer, Pyloric ligation model, Quercetin

\section{INTRODUCTION}

Gastric ulcer is one of the major gastrointestinal disorders, which occurs due to an imbalance between the offensive (gastric acid secretion) and defensive (gastric mucosal integrity) factors. ${ }^{1,2}$ The incidence of peptic ulcer is increased due to stress, smoking, alcohol, Helicobacter pylori and ingestion of non-steroidal anti-inflammatory drugs (NSAID) ${ }^{3-5}$ It has been suggested that reactive oxygen species (ROS), primarily super-oxide anions, hydroxyl radicals, and lipid peroxides, are the harmful species known to cause the gastric ulcer development6. To scavenge ROS, gastric cells have several enzymatic and non-enzymatic antioxidants including catalase (CAT), superoxide dismutase (SOD), glutathione peroxidase (GPx), endogenous glutathione (GSH) and sulfhydryl groups (NPSH), but excessive generation of ROS enhance lipid peroxidation and depletes these antioxidants enzymes. $^{6-9}$

There are many different experimental models of gastric ulcer induction, including ethanol and acetic acid2. Using such animal models, researchers simulate conditions to 
which humans may be exposed and, as a result, develop gastric ulcers. Ethanol is known as a cause of gastric damage by altering protective factors, including decreasing mucus production and blood circulation within the mucosa. ${ }^{10}$ In addition, the gastric damage caused by ethanol may be due to the generation of reactive species, decreased cell proliferation, and an exacerbated inflammatory response. ${ }^{11,12}$

The prevention or cure of peptic ulcers is one of the most important challenges confronting medicine nowadays, as it is certainly a major human illness affecting nearly $8 \%$ $10 \%$ of the global population, of which $5 \%$ suffer from gastric ulcers. ${ }^{13}$ Gastric ulcer therapy faces a major drawback because most of the drugs currently available in the market show limited efficacy against gastric diseases and are often associated with severe side effects. ${ }^{14,15}$

Controlling the formation of reactive species and secretion of gastric acid are essential for the treatment of these pathologies. In this context, medicinal plants containing a wide variety of antioxidants, such us phenolic acids, flavonoid, coumarins, tannins and terpenoids compounds, are some of the most attractive sources of new drugs and have been shown to produce promising results in the treatment of gastric ulcers. ${ }^{16-19}$

Quercetin is a bioflavonoid found in many plants. It is widely distributed in edible fruits and vegetables. ${ }^{4}$ It is weakly toxic drug and has been used in the treatment of allergy, bee sting and ulcer with no serious side effects in adults. ${ }^{20}$ It is a very strong antioxidant, prevents oxidant injury and cell death by several mechanisms such as scavenging oxygen free radicals. ${ }^{6,7}$ Its antioxidant potential is four times that of vitamin E8. It is potent inhibitor of lipid peroxidation..$^{9-11}$ It is also a proton pump inhibitor. ${ }^{10}$ Because of these properties of quercetin this scientific study is undertaken to evaluate its antiulcerogenic property in albino rats.

\section{METHODS}

\section{Plant collection and authentication of leaves}

The seeds of quercetin was procured from Mumbai region in the month of September-October (2017-18) and airdried at room temperature $\left(28 \pm 2^{\circ} \mathrm{C}\right)$ for a one week.

\section{Preparation of crude extract}

Seeds of quercetin were shade dried and coarsely powdered by using grinder mixer. The powdered material was macerated in sufficient quantity of distilled water with small quantity of chloroform to prevent fungal growth and kept for 7 days. During maceration it was shaken twice daily. On seventh day it was filtered, and the filtrate was concentrated on water bath $\left(45^{\circ} \mathrm{C}\right)$ to remove the solvent and to get sticky brown coloured extract i.e. aqueous extract of quercetin (AEQR). The extractive value of the extract was $16 \%$.

\section{Experimental animals}

The study was conducted on Albino rats (Wistar) of 200$250 \mathrm{~g}$ and maintained under standard conditions (room temperature $24-27^{\circ} \mathrm{C}$ and humidity $60-65 \%$ ) with $12 \mathrm{~h}$ light and dark cycle. The food in the form of dry pellets (Amrut Lab., hyd) and water were available ad libitum. The animal experiments were approved by the ethics committee of the institute.

\section{Chemicals and drugs}

Ethanol (Yashchem, pune), Aspirin (Research lab, Mumbai), Ranitidine (Cipla, Mumbai), Sucralfate (Dr. Reddys lab, Mumbai), Carboxy methyl cellulose (CMC), Trichloroacetic Acid (Research lab, Mumbai), Phenol reagent (Research lab, Pune), Bovine albumin serum (Research lab. fine Chem Industries, Mumbai), Std. phenol solution (Research lab, Pune), Conc. HCL (Research lab. Fine Chem Industries, Mumbai), NAOH (Research lab. Fine Chem Industries, Mumbai) were used in the study.

\section{Toxicity studies}

The acute toxicity study was done as per the OECD guidelines (407). The compounds were Administered orally in different doses, where $24 \mathrm{~h}$ toxicity was recorded to identify the toxic dose. No mortality and no signs of toxicity were found at the dose of $5000 \mathrm{mg} / \mathrm{kg}$ body weight of AEQR. Therefore, it might be considered that AEQR have an LD50 value above $5000 \mathrm{mg} / \mathrm{kg}$. Two doses $500 \mathrm{mg} / \mathrm{kg}$ and $1000 \mathrm{mg} / \mathrm{kg}$ were selected for present study.

\section{Experimental design}

\section{Gastric cytoprotection methods (ethanol induced ulcers)}

Albino rats (Wistar) of 200-250g are maintained under standard conditions (room temperature $24-27^{\circ} \mathrm{C}$ and humidity $60-65 \%$ ) with $12 \mathrm{~h}$ light and dark cycle. The food in the form of dry pellets (Amrut Lab., Hyd) and water were available ad - libitum. Rats of either sex were randomly divided in to 5 groups of 6 animals in each group.

- Group-I: Normal control

- Group-II: Ulcerated control (1ml ethanol, p.o.)

- Group-III: Sucralfate $(400 \mathrm{mg} / \mathrm{kg})$

- Group-IV: AEQR (500mg/kg, p.o.)

- Group-V: AEQR (1000mg/kg, p.o.)

Thirty minutes after the test or reference drug or the control vehicle treatment, $1 \mathrm{ml}$ of ethanol was orally administered to each rat. After $1 \mathrm{~h}$ the rats were euthanised with excess of anesthetic ether and stomach was cut open along the greater curvature, cleared of residual matter with saline and the inner surface was examined for ulceration. Ulcer index and \% ulcer protection were calculated by using the methods described earlier. ${ }^{8,9}$ 


\section{Aspirin-induced gastric mucosal damage}

Albino rats (Wistar) of 200-250g were selected, and fasted for $36 \mathrm{~h}$. Rats of either sex, were randomly divided in to 5 groups of 6 animals in each group.

- Group-I: Normal control

- Group-II: Ulcerated control (1\% CMC, $5 \mathrm{ml} / \mathrm{kg}$, p.o.)

- Group-III: Ranitidine $(50 \mathrm{mg} / \mathrm{kg})$

- Group-IV: AEQR (500mg/kg, p.o.)

- Group-V: AEQR (1000mg/kg, p.o.)

After $30 \mathrm{~min}$, aspirin suspended in $1 \% \mathrm{CMC}$ in water $(20 \mathrm{mg} / \mathrm{ml})$ at a dose of $500 \mathrm{mg} / \mathrm{kg}$ was administered orally to all the animals and $4 \mathrm{~h}$ later, the animals were sacrificed. The stomach was removed and open along the greater curvature. The number of ulcer spots in the glandular portion of the stomach were counted in both control and drug treated animals and the ulcer index was calculated. ${ }^{10-}$ 12

\section{Pyloric ligation method}

In this method albino rats were fasted in individual cages for $24 \mathrm{~h}$. Care was being taken to avoid coprophagy. Rats of either sex were randomly divided in to 5 groups of 6 animals in each group.

- Group-I: Normal control

- Group-II: Ulcerated control (1\% CMC, $5 \mathrm{ml} / \mathrm{kg}$, p.o.)

- Group-III: Ranitidine $(30 \mathrm{mg} / \mathrm{kg})$

- Group-IV: AEQR (500mg/kg, p.o.)

- Group-V: AEQR (1000mg/kg, p.o.)

AEQR or reference drug or control vehicle was administered $30 \mathrm{~min}$ prior to pyloric ligation.

Under light ether anesthesia, the abdomen was opened, and the pylorus was ligated. The abdomen was then sutured. At the end of $4 \mathrm{~h}$ after ligation, the animals were sacrificed with excess of anesthetic ether, and the stomach was dissected out. Gastric juice was collected, and its volume was measured. The glandular portion was then exposed and examined for ulceration. Ulcer index was determined..$^{8,12-14}$

\section{RESULTS}

In this study AEQR (500mg/kg), AEQR (1000mg/kg) has significant reduction of volume of gastric acid secretion when compared with other treatment groups.

In this study AEQR (500mg/kg), AEQR (1000mg/kg) has significant reduction of free acidity when compared with other treatment groups.

In this study AEQR (500mg/kg), AEQR (1000mg/kg) has significant reduction of volume of pepsin content when compared with other treatment groups.
Table 1: Effect of AESO on volume and $\mathrm{pH}$ of gastric content in pylorus ligated rats.

\begin{tabular}{|lll|}
\hline $\begin{array}{l}\text { Treatment groups } \\
\text { (mg/kg) }\end{array}$ & $\begin{array}{l}\text { Volume of } \\
\text { gastric juice }(\mathrm{ml})\end{array}$ & $\begin{array}{l}\text { pH of } \\
\text { gastric juice }\end{array}$ \\
\hline Normal control & $1.17 \pm 0.04$ & $3.85 \pm 0.04$ \\
\hline Ulcerated control & $5.26 \pm 0.12$ & $1.95 \pm 0.65$ \\
\hline $\begin{array}{l}\text { Ranitidine } \\
(30 \mathrm{mg} / \mathrm{kg})\end{array}$ & $3.91 \pm 0.61$ & $2.48 \pm 0.05$ \\
\hline AEQR $(500 \mathrm{mg} / \mathrm{kg})$ & $4.03 \pm 0.65$ & $3.94 \pm 0.08$ \\
\hline AEQR $(1000 \mathrm{mg} / \mathrm{kg})$ & $4.32 \pm 0.16$ & $3.23 \pm 0.10$ \\
\hline
\end{tabular}

Values are expressed as Mean \pm SEM. $* \mathrm{p}<0.05$, **p $<0.01$, as compared with ulcerated control using one way ANNOVA followed by Dunnet test

Table 2: Effect of AEQR on free acidity and total acidity in pylorus ligated rats.

\begin{tabular}{|lll|}
\hline $\begin{array}{l}\text { Treatment group } \\
(\mathrm{mg} / \mathrm{kg})\end{array}$ & $\begin{array}{l}\text { Free acidity } \\
(\mathrm{meq} / \mathrm{L} / \mathbf{1 0 0 g m})\end{array}$ & $\begin{array}{l}\text { Total acidity } \\
(\mathrm{meq} / \mathrm{L} / 100 \mathrm{gm})\end{array}$ \\
\hline Normal control & $9.16 \pm 0.60$ & $27.41 \pm 0.68$ \\
\hline Ulcerated control & $37.33 \pm 1.80$ & $74.14 \pm 1.70$ \\
\hline $\begin{array}{l}\text { Ranitidine } \\
(30 \mathrm{mg} / \mathrm{kg})\end{array}$ & $14.41 \pm 0.31$ & $27.46 \pm 0.76$ \\
\hline AEQR $(500 \mathrm{mg} / \mathrm{kg})$ & $24.66 \pm 0.66$ & $68.06 \pm 0.72$ \\
\hline AEQR $(1000 \mathrm{mg} / \mathrm{kg})$ & $22.60 \pm 0.93$ & $39.83 \pm 1.10$ \\
\hline $\begin{array}{l}\text { Values are expressed as Mean } \pm \text { SEM. *p }<0.05, * * p<0.01 \text {, as } \\
\text { compared with ulcerated control using one way ANNOVA } \\
\text { followed by Dunnet test }\end{array}$
\end{tabular}

In this study AEQR (500mg/kg), AEQR (1000mg/kg) has significant reduction ulcerative index when compared with other treatment groups.

Table 3: Effect of AESO on pepsin content in pylorus ligated rats.

\begin{tabular}{|c|c|}
\hline Treatment (mg/kg) & Pepsin content (mcg/ml) \\
\hline Normal control & $0.88 \pm 0.02$ \\
\hline Ulcerated control & $5.56 \pm 0.65$ \\
\hline Ranitidine $(30 \mathrm{mg} / \mathrm{kg})$ & $2.39 \pm 0.65$ \\
\hline AEQR $(500 \mathrm{mg} / \mathrm{kg})$ & $4.97 \pm 0.09$ \\
\hline AEQR (1000mg/kg) & $3.33 \pm 0.24$ \\
\hline
\end{tabular}

Table 4: Effect of AEQR on ulcer index and \% gastro protection in pyrolus ligated rats.

\begin{tabular}{|lll|}
$\begin{array}{l}\text { Treatment group } \\
(\mathrm{mg} / \mathrm{kg})\end{array}$ & $\begin{array}{l}\text { Ulcer index } \\
\text { (Mean } \pm \text { SEM) }\end{array}$ & $\begin{array}{l}\text { \% Gastro } \\
\text { protection }\end{array}$ \\
\hline Normal control & - & 100 \\
\hline Ulcerated control & $4.7 \pm 0.29$ & - \\
\hline Ranitidine $(30 \mathrm{mg} / \mathrm{kg})$ & $1.88 \pm 0.11$ & 60 \\
\hline AEQR $(500 \mathrm{mg} / \mathrm{kg})$ & $4.21 \pm 0.11$ & 29.70 \\
\hline AEQR $(1000 \mathrm{mg} / \mathrm{kg})$ & $2.35 \pm 0.15$ & 62 \\
\hline
\end{tabular}

Values are expressed as Mean \pm SEM. $* \mathrm{p}<0.05$, $* * \mathrm{p}<0.01$, as compared with ulcerated control using one way ANNOVA followed by Dunnet test 
In this study AEQR $(500 \mathrm{mg} / \mathrm{kg})$, AEQR $(1000 \mathrm{mg} / \mathrm{kg})$ has significant effect on ulcer index and \% gastro protection when compared with other treatment groups.

\section{Table 5: Effect of AESO on ulcer index and \% gastro protection in aspirin induced gastric lesion in rats.}

\begin{tabular}{|lll|}
\hline $\begin{array}{l}\text { Treatment group } \\
\text { (mg/kg) }\end{array}$ & $\begin{array}{l}\text { Ulcer index } \\
\text { (Mean } \pm \text { SEM) }\end{array}$ & $\begin{array}{l}\text { \% Gastro } \\
\text { protection }\end{array}$ \\
\hline Normal control & - & 100 \\
\hline Ulcerated control & $2.25 \pm 0.21$ & - \\
\hline Ranitidine $(30 \mathrm{mg} / \mathrm{kg})$ & $0.45 \pm 0.11$ & 80 \\
\hline AEQR $(500 \mathrm{mg} / \mathrm{kg})$ & $2.25 \pm 0.07$ & 38.39 \\
\hline AEQR $(1000 \mathrm{mg} / \mathrm{kg})$ & $0.95 \pm 0.15$ & 74.77 \\
\hline
\end{tabular}

Values are expressed as Mean \pm SEM. $* p<0.05, * * p<0.01$, as compared with ulcerated control using one way ANNOVA followed by Dunnet test

In this study AEQR $(500 \mathrm{mg} / \mathrm{kg}), \mathrm{AEQR}(1000 \mathrm{mg} / \mathrm{kg})$ has significant effect on ulcer index and \% gastro protection when compared with other treatment groups.

Table 6: Effect of AESO on ulcer index and \% gastro protection in ethanol induced gastric ulcer in rats

\begin{tabular}{|lll|}
\hline $\begin{array}{l}\text { Treatment group } \\
\text { (mg/kg) }\end{array}$ & $\begin{array}{l}\text { Ulcer index } \\
(\text { Mean } \pm \text { SEM) })\end{array}$ & $\begin{array}{l}\text { \% Gastro } \\
\text { protection }\end{array}$ \\
\hline Normal control & - & 100 \\
\hline Ulcerated control & $4.72 \pm 0.07$ & \\
\hline Ranitidine $(30 \mathrm{mg} / \mathrm{kg})$ & $1.2 \pm 0.29$ & 74.57 \\
\hline AEQR $(500 \mathrm{mg} / \mathrm{kg})$ & $2.99 \pm 0.21$ & 58.33 \\
\hline AEQR $(1000 \mathrm{mg} / \mathrm{kg})$ & $2.16 \pm 0.11$ & 65.27 \\
\hline
\end{tabular}

\section{DISCUSSION}

Ethanol-induced gastric mucosal damage was seen in the glandular portion of stomach as elongated red streak. The fore-stomach or rumen (non-glandular portion) was spared. This may be due to squamous epithelium that covers its surface. ${ }^{5}$ The ulcer lesions were confined to the mucosal crests, and this may be due to the presence of these folds at the time of exposure to ethanol. ${ }^{6}$ Ethanol- induced damage to gastric mucosa is associated with a significant production of free radicals, leading to increased lipid peroxidation. ${ }^{7}$ This causes damage to cell membranes.

In present study, pre-treatment with quercetin in the dose of $50 \mathrm{mg} / \mathrm{kg}$ reduced total score, ulcer incidence and ulcer index as compared to control group (I A). The $\mathrm{p}$ value was $<0.001$ (highly significant).

Quercetin is a flavonoid and has potent lipid peroxidation inhibiting property. ${ }^{10,11}$ As lipid peroxidation is suggested to be one of the important mechanisms of Ethanol induced gastric ulcer, quercetin probably acts by inhibiting the lipid peroxidation.

Even though ranitidine pre-treated animals (I B) showed significant reduction in total score, ulcer incidence and ulcer index as compared to control group (I A) ( $p<0.05$ ), it was inferior when compared to quercetin pre-treated group $(p<0.05)$. This indicates the superiority of quercetin over ranitidine in preventing ethanol-induced gastric mucosal damage.

Ranitidine acts by blocking $\mathrm{H} 2$ receptors and thus inhibits gastric acid secretion. Ethanol-induced ulcers occur instantaneously irrespective of the acid content in the stomach. As the mechanism of gastric mucosal damage by ethanol is different, $\mathrm{H} 2$ blockers are only partially effective in inhibiting ethanol-induced gastric mucosal damage. This finding correlates with the study conducted by Robert et al. ${ }^{11}$

Normal amount of gastric acid is also necessary for the development of gastric ulcers produced by NSAIDs. In the present study, in indomethacin-induced gastric ulcer model, the total score, ulcer incidence and ulcer index in ranitidine pre-treated animals (II B) were significantly reduced as compared to control group (II A) ( $\mathrm{p}<0.01)$. As the $\mathrm{H} 2$ blockers reduce the gastric acid secretion, they are effective in preventing the gastric mucosal damage produced by NSAIDs. In quercetin pre-treated animals (II C) even though the total score, ulcer incidence and ulcer index were significantly reduced when compared to control group ( $\mathrm{p}<0.01$ ), the total score and ulcer index were only slightly higher as compared to ranitidine pre-treated group (statistically not significant; $\mathrm{p}>0.05$ ). So, the protection given by quercetin against indomethacin-induced gastric mucosal damage is nearly comparable to that by ranitidine.

In a study conducted by Rao CV et al, quercetin significantly decreased the acid and pepsin output of gastric contents. ${ }^{11}$ In another study conducted by Elango V et al, quercetin was shown to inhibit the proton pump and increase the synthesis of local prostaglandins. ${ }^{3,10}$ Thus it appears that quercetin exert its gastric mucosal protection against indomethacin-induced lesions by decreasing acid and pepsin content of the stomach and by increasing local prostaglandin synthesis. In another study, Yoshikawa et al, reported the role of active oxygen species and lipid peroxidation in the pathogenesis of gastric mucosal injury induced by indomethacin. ${ }^{8,11}$ As quercetin is a potent inhibitor of lipid peroxidation, it prevents indomethacininduced gastric mucosal damage.

In present study quercetin has been found to be better than ranitidine in preventing ethanol induced gastric mucosal damage and nearly equally effective as ranitidine in preventing indomethacin-induced gastric mucosal damage (Table 1 to Table 5).

\section{CONCLUSION}

In conclusion, it appears that quercetin possess antiulcerogenic principles like flavanoids, phenolic compound and caratinoid. These phytoconstituents provides protection against gastric mucosal damage induced by pylorus ligation, aspirin and ethanol, through inhibition of 
gastric acid, pepsin, histamine and free radical and stimulation of mucus secretion.

Funding: No funding sources

Conflict of interest: None declared

Ethical approval: The study was approved by the Institutional Ethics Committee

\section{REFERENCES}

1. Rice-evans CA, Miller NJ, Bolwell PG, Bramley PM, Pridham JB. The relative antioxidant activities of plant-derived polyphenolic flavonoids. Free Radical Res. 1995 Jan 1;22(4):375-83.

2. Chen ZY, Chan PJ, HO KY, Fung KP, Wang J. Antioxidant activity of natural flavonoids is governed by number and location of their aromatic groups. Chem Phys Lipids. 1996;79:157-63.

3. Elango V, Oliver C, Raghu PS. Antiulcer activity of the leaf ethanolic extract of Mimosa pudica in rats. Hygeia J Drugs Med. 2012;4(1):34-40.

4. Rao CV, Vijayakumar M. Effect of quercetin, flavonoids and $\alpha$-tocopherol, an antioxidant vitamin on experimental reflux oesophagitis in rats. European J Pharmacol. 2008 Jul 28;589(1-3):233-8.

5. Vidhya A, Indira M. Protective effect of quercetin in the regression of ethanol-induced hepatotoxicity. Indian J Pharmaceut Sci. 2009 Sep;71(5):527.

6. Laurence DR, Bacharach AL. Evaluation of Drug Activities: Pharmacometrics. $1^{\text {st }}$ ed. New York: Academic Press; 1964(2):510.

7. Sunita J, Devdas S. Modification of duodenal ulcer by calcium channel blockers in rats. Indian J Pharmacol. 1996 Jul 1;28(3):167.

8. Robert A, James E. Nezamis, Cleo Lancaster, Alexander J. Hanchar. Cytoprotection by prostaglandins in rats. Gastroenterology. 1979;77(3):433-43.

9. Lacy ER, Ito S. Microscopic analysis of ethanol damage to rat gastric mucosa after treatment with a prostaglandin. Gastroenterol. 1982 Sep 1;83(3):61925.
10. Szelenyi I, Brune K. Possible role of oxygen free radicals in ethanol-induced gastric mucosal damage in rats. Digestive Dis Sci. 1988 Jul 1;33(7):865-71.

11. Yoshikawa T, Naito Y, Kishi A, Tomii T, Kaneko T, Iinuma $S$, et al. Role of active oxygen, lipid peroxidation, and antioxidants in the pathogenesis of gastric mucosal injury induced by indomethacin in rats. Gut. 1993 Jun 1;34(6):732-7.

12. Laurence DR, Bennet PN, Brown MJ. Clinical Pharmacology. $8^{\text {th }}$ ed. Singapore: Longman Publishers Pvt Ltd; 1997:567-578.

13. Soll AH. Pathogenesis of peptic ulcer and implications for therapy. N Engl J Med. 1990;322:909-16.

14. Desai JK, Goyal RK, Parmar NS. Pathogenesis of peptic ulcer disease and current trends in therapy. Indian J Physiol Pharmacol. 1997;41(1):3-15.

15. Suolinna EM, Buchsbaun RN, Racker E.The effect of flavonoids on aerobic glycolysis and growth of tumour cells. Cancer Res. 1975;35:1865-72.

16. Havsteen B. Flavonoids, a class of natural products of high pharmacological potency. Biochem Pharmacol. 1983;32:1141-8.

17. Bors W, Heller W, Michel C, Saren M. Flavonoids as antioxidants: determination of radical scavenging efficiencies. Methods Enzymol. 1990;186:343-55.

18. Park C, So HS, Shin CH. Quercetin protects the hydrogen peroxide induced apoptosis via inhibition of mitochondrial dysfunction in $\mathrm{H} 9 \mathrm{c} 2$ cardiomyoblast cells. Biochem Pharmacol. 2003;66(7):1287-95.

19. Sedlak J, Lindsay RH. Estimation of total, protein bound, and nonprotein sulfhydryl groups in tissue with Ellman's reagent. Analytical Biochemistry. 1968;25:192-205.

20. Kulkarni SK. Handbook of Experimental Pharmacology. Vallabh Prakashan New Delhi. 2005;3:19-84.

Cite this article as: Shaik AH, Prasadu VSM. A randomised study of evaluation of antiulcerogenic activity of quercetin in rats. Int $\mathrm{J}$ Basic Clin Pharmacol 2018;7:2368-72. 